\title{
Tissue Fractions of Cadmium in Two Hyperaccumulating Jerusalem Artichoke Genotypes
}

\author{
Xiaohua Long, ${ }^{1}$ Ni Ni, ${ }^{1,2}$ Zhaopu Liu, ${ }^{1}$ Zed Rengel, ${ }^{3}$ Xin Jiang, ${ }^{2}$ and Hongbo Shao ${ }^{1,4}$ \\ ${ }^{1}$ Jiangsu Provincial Key Laboratory of Marine Biology, College of Resources and Environmental Sciences, \\ Nanjing Agricultural University, Nanjing 210095, China \\ ${ }^{2}$ State Key Laboratory of Soil and Sustainable Agriculture, Institute of Soil Science, Chinese Academy of Sciences, \\ 71 East Beijing Road, Nanjing 210008, China \\ ${ }^{3}$ School of Earth and Environment, The University of Western Australia, 35 Stirling Highway, Crawley, WA 6009, Australia \\ ${ }^{4}$ Key Laboratory of Coastal Biology \& Bio-Resources Utilization, Yantai Institute of Coastal Zone Research (YIC), \\ Chinese Academy of Sciences (CAS), Yantai 264003, China
}

Correspondence should be addressed to Zhaopu Liu; zhaopuliu@163.com and Hongbo Shao; shaohongbochu@126.com

Received 15 March 2014; Accepted 26 March 2014; Published 14 April 2014

Academic Editor: Xu Gang

Copyright (C) 2014 Xiaohua Long et al. This is an open access article distributed under the Creative Commons Attribution License, which permits unrestricted use, distribution, and reproduction in any medium, provided the original work is properly cited.

\begin{abstract}
In order to investigate the mechanisms in two Jerusalem artichoke (Helianthus tuberosus L.) genotypes that hyperaccumulate Cd, a sand-culture experiment was carried out to characterize fractionation of $\mathrm{Cd}$ in tissue of Cd-hyperaccumulating genotypes $\mathrm{NY}_{2}$ and $\mathrm{NY}_{5}$. The sequential extractants were: $80 \% \mathrm{v} / \mathrm{v}$ ethanol $\left(\mathrm{F}_{\mathrm{E}}\right)$, deionized water $\left(\mathrm{F}_{\mathrm{W}}\right), 1 \mathrm{M} \mathrm{NaCl}\left(\mathrm{F}_{\mathrm{NaCl}}\right), 2 \% \mathrm{v} / \mathrm{v}$ acetic acid $\left(\mathrm{F}_{\mathrm{Acet}}\right)$, and $0.6 \mathrm{M} \mathrm{HCl}\left(\mathrm{F}_{\mathrm{HCl}}\right)$. After 20 days of treatments, $\mathrm{NY}_{5}$ had greater plant biomass and greater Cd accumulation in tissues than $\mathrm{NY}_{2}$. In both genotypes the $\mathrm{F}_{\mathrm{NaCl}}$ fraction was the highest in roots and stems, whereas the $\mathrm{F}_{\mathrm{Acet}}$ and $\mathrm{F}_{\mathrm{HCl}}$ fractions were the highest in leaves. With an increase in Cd concentration in the culture solution, the content of every Cd fraction also increased. The $\mathrm{F}_{\mathrm{W}}$ and $\mathrm{F}_{\mathrm{NaCl}}$ ratios in roots were lower in $\mathrm{NY}_{5}$ than in $\mathrm{NY}_{2}$, while the amount of other $\mathrm{Cd}$ forms was higher. It implied that, in high accumulator, namely, $\mathrm{NY}_{5}$, the complex of insoluble phosphate tends to be shaped more easily which was much better for Cd accumulation. Besides, translocation from plasma to vacuole after combination with protein may be one of the main mechanisms in Cd-accumulator Jerusalem artichoke genotypes.
\end{abstract}

\section{Introduction}

$\mathrm{Cd}$ is one of biotoxic metal elements, which has strong chemical activity and long-term toxicity and is relatively mobile in plants $[1,2]$. It is also one of the major environmental pollutants. Moderate Cd contamination of arable soils can result in considerable $\mathrm{Cd}$ accumulation in edible parts of crops [3-5]. Cd can be present in plant tissues in concentrations that are nontoxic to crops but can contribute to substantial Cd dietary intake by humans [6].

Existing methods of cleaning up Cd-contaminated soils are expensive, such as mechanical removal and chemical engineering [7]. Comparatively, phytoextraction has a great potential in ameliorating Cd-contaminated soils because it is a cost-effective, environmentally friendly approach applicable to large areas $[8,9]$.
Plant resistance to metal toxicity stress includes avoidance and tolerance [10]. Avoidance frequently results in exclusion, whereas accumulation in plant tissues must be linked with internal tolerance mechanisms. These tolerance mechanisms might rely on metal being retained mainly in roots, with transport to photosynthetically active above-ground tissues impeded. In addition, tolerance may be underpinned by metals existing in nonactive (nontoxic) forms in plant tissues. Such nontoxic forms may, for example, include binding of metals in the cell wall or complexation with organic acid and proteins mostly in the vacuole [11].

We have previously reported that two Jerusalem artichoke genotypes, $\mathrm{NY}_{2}$ and $\mathrm{NY}_{5}$, when grown in Cd contaminated soils did not suffer from Cd toxicity, even though $\mathrm{Cd}$ concentration not only in roots but also in leaves and stems exceeded $100 \mathrm{mg} \mathrm{kg}^{-1}$ dry weight [12], which is the 
TABLE 1: Extractants and relevant extracted chemical forms of Cd.

\begin{tabular}{lcl}
\hline Extract ion reagent & Code & Predominant forms of extracted Cd \\
\hline $80 \% \mathrm{v} / \mathrm{v}$ ethanol & $\mathrm{F}_{\mathrm{E}}$ & Cd-nitrate, Cd-chloride, Cd-amino acid complexes \\
Deionized water & $\mathrm{F}_{\mathrm{W}}$ & Soluble Cd-organic acid complexes, Cd $\left(\mathrm{H}_{2} \mathrm{PO}_{4}\right)_{2}$ \\
$1 \mathrm{M} \mathrm{NaCl}$ & $\mathrm{F}_{\mathrm{NaCl}}$ & Cd-pectates, Cd-polypeptide, or Cd-protein complexes \\
$2 \% \mathrm{v} / \mathrm{v}$ acetic acid & $\mathrm{F}_{\mathrm{Acet}}$ & Sparingly soluble CdHPO $, \mathrm{Cd} \mathrm{CO}_{3}, \mathrm{PO}$, and/or other Cd-phosphate complexes \\
$0.6 \mathrm{M} \mathrm{HCl}$ & $\mathrm{F}_{\mathrm{HCl}}$ & Cd-oxalate \\
\hline
\end{tabular}

main feature of hyperaccumulators. Hence, $\mathrm{NY}_{2}$ and $\mathrm{NY}_{5}$ genotypes showed a potential to be used in phytoremediation of Cd-contaminated soils via phytoextraction. However, the research so far has mainly concentrated on Cd accumulation and plant physiological properties rather than on $\mathrm{Cd}$ chemical forms in Jerusalem artichoke genotypes. The $\mathrm{Cd}$ chemical forms in plant tissues are expected to be linked to $\mathrm{Cd}$ tolerance via detoxication mechanisms. An understanding of Cd-tolerance mechanisms in Jerusalem artichoke genotypes is a prerequisite for quick screening ofgermplasm for improved Cd accumulation and tolerance. This study was aimed at characterizing the distribution of Cd chemical forms in Jerusalem artichoke genotypes that hyperaccumulate $\mathrm{Cd}$.

\section{Materials and Methods}

2.1. Plants. Two Jerusalem artichoke (Helianthus tuberosus L.) genotypes, $\mathrm{NY}_{2}$ and $\mathrm{NY}_{5}$, were selected from the Nanjing Agricultural University Experimental Station ("863 Program") at Laizhou County in Shandong Province, China. Previous work [12] indicated that these two genotypes have the capacity to hyperaccumulate $\mathrm{Cd}$.

2.2. Experimental Setup. The tests were carried out in a greenhouse at Nanjing Agricultural University (N32 $2^{\prime} 6.25^{\prime \prime}$, E18 $\left.50^{\prime} 23.47^{\prime \prime}\right)$, Nanjing, China. The average temperature throughout the test period was between $26.6 \pm 4.4^{\circ} \mathrm{C}$ (daytime) and $22.0 \pm 2.4^{\circ} \mathrm{C}$ (night), and the relative humidity was $61.5 \pm 1.3 \%$ (daytime) and $68.0 \pm 1.9 \%$ (night). Tuber slices with buds were germinated on sand moistened with $1 / 2$ Hoagland nutrient solution in an incubator. The nutrient solution was replaced every second day. At trefoil stage, young plants were transplanted into porcelain pots. About one week later, Cd treatments were imposed $\left(0,2.5,5.0\right.$, or $10 \mathrm{mg} \mathrm{L}^{-1}$ as $\mathrm{CdCl}_{2} \cdot 2.5 \mathrm{H}_{2} \mathrm{O}$ ). Each $\mathrm{Cd}$ treatment was replicated in three pots, and two uniform plants were allowed to grow in each pot at a uniform spacing. Sampling was carried out after 3week treatment duration.

2.3. Plant Sampling and Analysis. Roots were washed in deionized water, and then shoots and roots were separated, weighed, and used for sequential extraction to determine chemical forms of Cd $[13,14]$. Briefly, 1 gram fresh leaf, stem, or root material was cut into pieces of $1-2 \mathrm{~mm}^{2}$, transferred into a beaker with $10 \mathrm{~mL}$ of extractant (Table 1), and kept at $25^{\circ} \mathrm{C}$ overnight (20-24 h) on a shaker [15]. The following day the solutes were saved, and the residues were extracted again overnight with the next extractant. In total, there were five sequential extractions.

The extracts were digested with a concentrated acid mixture of $\mathrm{HNO}_{3}-\mathrm{HClO}_{4}(3: 1 \mathrm{v} / \mathrm{v})$ and heated at $160^{\circ} \mathrm{C}$ for $5 \mathrm{~h}$. After cooling, the extracts were diluted, filtered, and made up to $25 \mathrm{~mL}$ with $5 \% \mathrm{v} / \mathrm{v} \mathrm{HNO}_{3}$. The $\mathrm{Cd}$ concentration in the extract was determined by inductively coupled plasma atomic emission spectroscopy (ICP-AES, IRIS Intrepid II XSP; Thermo Electron Company, USA). The analyses were carried out in triplicate.

2.4. Symbol Meanings. $\mathrm{F}_{\mathrm{E}}, \mathrm{F}_{\mathrm{W}}, \mathrm{F}_{\mathrm{NaCl}}, \mathrm{F}_{\text {Acet }}$, and $\mathrm{F}_{\mathrm{HCl}}$ show the amounts of the Cd-containing fractions extracted by ethanol, water, $\mathrm{NaCl}$, acetic acid, and $\mathrm{HCl}$, respectively.

2.5. Statistical Analysis. All statistical tests were performed using SPSS 13.0. Two-way ANOVA was used to determine the significance of genotype and $\mathrm{Cd}$ treatment effects on $\mathrm{Cd}$ forms. Mean treatment differences were separated by the least significant difference $\left(\mathrm{LSD}_{0.05}\right)$ test if $F$-tests were significant $(P \leq 0.05$; Fisher's protected test).

\section{Results}

3.1. Effects of Cd Treatments on the Biomass and Its Components of Two H. tuberosus Genotypes. Even though the two Jerusalem artichoke genotypes showed good tolerance to $\mathrm{Cd}$ toxicity, $\mathrm{NY}_{2}$ showed some wilting in the high-Cd treatments. Compared to control, the Cd treatment $\left(2.5\right.$ and $\left.10 \mathrm{mg} \mathrm{kg}^{-1}\right)$ decreased leaf, stem, root, and total biomass for both $\mathrm{NY}_{2}$ and $\mathrm{NY}_{5}$ (Table 2). In contrast, the $5 \mathrm{mg} \mathrm{kg}^{-1} \mathrm{Cd}$ treatment increased the biomass and its components for $\mathrm{NY}_{2}$. In every $\mathrm{Cd}$ treatment, the biomass and its components of $\mathrm{NY}_{5}$ were lower than in the $0 \mathrm{mg} \mathrm{kg}^{-1} \mathrm{Cd}$ supply, but there was no significant difference.

\subsection{Chemical Forms of Cd in Plants}

3.2.1. Effects of Cd Treatments on Cd Chemical Forms of Roots in Two Jerusalem Artichoke Genotypes. As can be seen from Table 3, the distribution ratios raised with increased $\mathrm{Cd}$ supply in both $\mathrm{NY}_{2}$ and $\mathrm{NY}_{5}$. In control group, the difference between the five forms was not remarkable. In treatment group, the $\mathrm{Fw}$ ratio increased and was higher than the $\mathrm{F}_{\mathrm{R}}$ ratio in $\mathrm{NY}_{2}$ and $\mathrm{NY}_{5} . \mathrm{F}_{\mathrm{NACl}}$ occupied the most proportion in both two Jerusalem artichoke genotypes; secondly, $\mathrm{F}_{\text {Acet }}$ and $\mathrm{F}_{\mathrm{E}}$ were the least. 
TABLE 2: Effects of different cadmium treatments on the fresh biomass of two $H$. tuberosus genotypes.

\begin{tabular}{|c|c|c|c|c|c|}
\hline Genotype & Cd supply $\left(\mathrm{mg} \mathrm{L}^{-1}\right)$ & Leaves $\left(\mathrm{g} \mathrm{plant}^{-1}\right)$ & Stem $\left(\right.$ g plant $\left.^{-1}\right)$ & Root (g plant ${ }^{-1}$ ) & Whole plant (g) \\
\hline \multirow{4}{*}{$\mathrm{NY}_{2}$} & 0 & $24.3^{\mathrm{a}}$ & $10.7^{\mathrm{ab}}$ & $23.3^{\mathrm{a}}$ & $58.2^{\mathrm{a}}$ \\
\hline & 2.5 & $24.6^{\mathrm{a}}$ & $11.1^{\mathrm{ab}}$ & $21.1^{\mathrm{a}}$ & $56.8^{\mathrm{a}}$ \\
\hline & 5 & $28.5^{\mathrm{a}}$ & $13.0^{\mathrm{a}}$ & $28.4^{\mathrm{a}}$ & $69.9^{\mathrm{a}}$ \\
\hline & 10 & $15.4^{\mathrm{b}}$ & $8.3^{\mathrm{b}}$ & $11.1^{\mathrm{b}}$ & $34.9^{\mathrm{b}}$ \\
\hline \multirow{4}{*}{$\mathrm{NY}_{5}$} & 0 & $29.8^{\mathrm{a}}$ & $13.0^{\mathrm{a}}$ & $25.8^{\mathrm{a}}$ & $68.5^{\mathrm{a}}$ \\
\hline & 2.5 & $29.1^{\mathrm{a}}$ & $12.8^{\mathrm{a}}$ & $17.1^{\mathrm{b}}$ & $58.9^{\mathrm{a}}$ \\
\hline & 5 & $30.1^{\mathrm{a}}$ & $13.9^{\mathrm{a}}$ & $20.9^{\mathrm{ab}}$ & $64.9^{\mathrm{a}}$ \\
\hline & 10 & $27.5^{\mathrm{a}}$ & $12.7^{\mathrm{a}}$ & $16.9^{\mathrm{b}}$ & $57.1^{\mathrm{a}}$ \\
\hline
\end{tabular}

Different letters within a column indicate the significant differences among the treatments $(P \leq 0.05, n=3)$.

TABLE 3: Fractionation of Cd in roots of two Jerusalem artichoke genotypes.

\begin{tabular}{ccccccc}
\hline Genotype & Cd supply $\left(\mathrm{mg} \mathrm{L}^{-1}\right)$ & $\mathrm{F}_{\mathrm{E}}\left(\mu \mathrm{gg}^{-1}\right)$ & $\mathrm{F}_{\mathrm{W}}\left(\mu \mathrm{gg}^{-1}\right)$ & $\mathrm{F}_{\mathrm{NaCl}}\left(\mu \mathrm{gg}^{-1}\right)$ & $\mathrm{F}_{\text {Acet }}\left(\mu \mathrm{gg}^{-1}\right)$ & $\mathrm{F}_{\mathrm{HCl}}\left(\mu \mathrm{gg}^{-1}\right)$ \\
\hline \multirow{2}{*}{$\mathrm{NY}_{2}$} & 0 & $11^{\mathrm{a}}$ & $8.4^{\mathrm{a}}$ & $11^{\mathrm{a}}$ & $12^{\mathrm{a}}$ & $8.3^{\mathrm{a}}$ \\
& 2.5 & $41^{\mathrm{c}}$ & $48^{\mathrm{c}}$ & $223^{\mathrm{a}}$ & $127^{\mathrm{b}}$ & $35^{\mathrm{c}}$ \\
& 5 & $38^{\mathrm{b}}$ & $103^{\mathrm{b}}$ & $655^{\mathrm{a}}$ & $127^{\mathrm{b}}$ & $54^{\mathrm{b}}$ \\
& 10 & $62^{\mathrm{b}}$ & $150^{\mathrm{b}}$ & $1675^{\mathrm{a}}$ & $329^{\mathrm{b}}$ & $91^{\mathrm{b}}$ \\
$\mathrm{NY}_{5}$ & 0 & $3.7^{\mathrm{c}}$ & $4.9 \mathrm{~b}^{\mathrm{c}}$ & $13^{\mathrm{a}}$ & $7.9^{\mathrm{b}}$ & $7.8^{\mathrm{b}}$ \\
& 2.5 & $51^{\mathrm{c}}$ & $36^{\mathrm{c}}$ & $304^{\mathrm{a}}$ & $113^{\mathrm{b}}$ & $33^{\mathrm{c}}$ \\
& 5 & $55^{\mathrm{b}}$ & $83^{\mathrm{b}}$ & $469^{\mathrm{a}}$ & $259^{\mathrm{ab}}$ & $63^{\mathrm{b}}$ \\
& 10 & $80^{\mathrm{b}}$ & $117^{\mathrm{b}}$ & $1280^{\mathrm{a}}$ & $387^{\mathrm{b}}$ & $245^{\mathrm{b}}$ \\
\hline
\end{tabular}

Different letters within a row indicate significant differences among the fractions $(P \leq 0.05, n=3)$.

TABLE 4: Cd chemical forms of stems in two Jerusalem artichoke genotypes.

\begin{tabular}{|c|c|c|c|c|c|c|}
\hline Genotype & Cd supply $\left(\mathrm{mg} \mathrm{L}^{-1}\right)$ & $F_{R}\left(\mu g^{-1}\right)$ & $\mathrm{F}_{\mathrm{W}}\left(\mu \mathrm{gg}^{-1}\right)$ & $\mathrm{F}_{\mathrm{NaCl}}\left(\mu \mathrm{gg}^{-1}\right)$ & $\mathrm{F}_{\text {Acet }}\left(\mu \mathrm{gg}^{-1}\right)$ & $\mathrm{F}_{\mathrm{HCl}}\left(\mu \mathrm{gg}^{-1}\right)$ \\
\hline \multirow{4}{*}{$\mathrm{NY}_{2}$} & 0 & $7.0^{\mathrm{a}}$ & $5.8^{\mathrm{a}}$ & $6.6^{\mathrm{a}}$ & $8.7^{\mathrm{a}}$ & $6.4^{\mathrm{a}}$ \\
\hline & 2.5 & $17^{\mathrm{c}}$ & $14^{\mathrm{c}}$ & $126^{\mathrm{a}}$ & $66^{\mathrm{b}}$ & $35^{\mathrm{b}}$ \\
\hline & 5 & $18^{\mathrm{b}}$ & $28^{\mathrm{b}}$ & $278^{\mathrm{a}}$ & $48^{\mathrm{b}}$ & $34^{\mathrm{b}}$ \\
\hline & 10 & $22^{\mathrm{b}}$ & $43^{\mathrm{b}}$ & $315^{\mathrm{a}}$ & $91^{b}$ & $57^{\mathrm{b}}$ \\
\hline \multirow{4}{*}{$\mathrm{NY}_{5}$} & 0 & $2.9^{c}$ & $5.3^{\mathrm{b}}$ & $7.4^{\mathrm{a}}$ & $6.5^{\mathrm{ab}}$ & $6.4^{\mathrm{ab}}$ \\
\hline & 2.5 & $13^{\mathrm{c}}$ & $13^{\mathrm{c}}$ & $99^{\mathrm{a}}$ & $54^{\mathrm{b}}$ & $31^{\mathrm{bc}}$ \\
\hline & 5 & $16^{\mathrm{a}}$ & $17^{\mathrm{a}}$ & $195^{\mathrm{a}}$ & $92^{\mathrm{a}}$ & $47^{\mathrm{a}}$ \\
\hline & 10 & $32^{\mathrm{c}}$ & $49^{\mathrm{bc}}$ & $393^{\mathrm{a}}$ & $135^{\mathrm{b}}$ & $131^{\mathrm{b}}$ \\
\hline
\end{tabular}

Different letters within a row indicate the significant differences among the forms $(P \leq 0.05, n=3)$.

There were some differences of the five main chemical forms in roots between $\mathrm{NY}_{2}$ and $\mathrm{NY}_{5}$. The $\mathrm{Fw}$ ratio was higher in $\mathrm{NY}_{2}$ than that in $\mathrm{NY}_{5}$. Water extracts the soluble $\mathrm{Cd}$ organic acid complex, $\mathrm{Cd}\left(\mathrm{H}_{2} \mathrm{PO}_{4}\right)_{2}$, which is poisonous and tends to cause harm to plants. The $\mathrm{F}_{\text {Acet }}$ ratio of high accumulator was higher than low accumulator, while the Fw ratio was lower. Ethylic acid extracts unsoluble $\mathrm{Cd} \mathrm{HPO}_{4}$, $\mathrm{Cd}_{3}(\mathrm{PO})_{2}$, or Cd-phosphate complexes, which may be better for $\mathrm{Cd}$ accumulation in high accumulator.

3.2.2. Effects of Cd Treatments on Cd Chemical Forms of Stems in Two Jerusalem Artichoke Genotypes. We can see from Table 4 that the distribution ratios were raised with increased Cd supply in both $\mathrm{NY}_{2}$ and $\mathrm{NY}_{5}$. Compared to the roots, every proportion of the five chemical forms in stems decreased greatly. Similarly, $\mathrm{F}_{\mathrm{NaCl}}$ occupied the most proportion in both two Jerusalem artichoke genotypes; secondly $\mathrm{F}_{\text {Acet }}$ and $\mathrm{F}_{\mathrm{R}}$ were the least. The $\mathrm{Fw}$ ratio was higher in $\mathrm{NY}_{2}$ than that in $\mathrm{NY}_{5}$. The $\mathrm{F}_{\text {Acet }}$ ratio of high accumulator was higher than low accumulator, while the $\mathrm{Fw}$ ratio was lower.

3.2.3. Effects of Cd Treatments on Cd Chemical Forms of Leaves in Two Jerusalem Artichoke Genotypes. The distribution ratios were raised with increased Cd supply in both $\mathrm{NY}_{2}$ and $\mathrm{NY}_{5}$ (Table 5). Compared to stems, the five forms were further reduced in different degrees, especially $\mathrm{F}_{\mathrm{NaCl}}$. $\mathrm{F}_{\text {Acet }}$ covered the most part, $38 \%$ and $41 \%$, respectively, in $\mathrm{NY}_{2}$ and $\mathrm{NY}_{5}$.

The $\mathrm{F}_{\mathrm{W}}$ ratio was the lowest in leaf instead of the $\mathrm{F}_{\mathrm{R}}$ ratio in $\mathrm{NY}_{2}$. Ethanol extracts Cd-nitrate, Cd-chloride, and Cdamino acid. The lowest $\mathrm{F}_{\mathrm{NaCl}}$ ratio might be beneficial for 
TABLE 5: Cd chemical forms of leaves in two Jerusalem artichoke genotypes.

\begin{tabular}{|c|c|c|c|c|c|c|}
\hline Genotype & Cd supply $\left(\mathrm{mg} \mathrm{L}^{-1}\right)$ & $F_{R}\left(\mu g^{-1}\right)$ & $\mathrm{F}_{\mathrm{W}}\left(\mu \mathrm{gg}^{-1}\right)$ & $\mathrm{F}_{\mathrm{NaCl}}\left(\mu \mathrm{gg}^{-1}\right)$ & $F_{\text {Acet }}\left(\mu g^{-1}\right)$ & $\mathrm{F}_{\mathrm{HCl}}\left(\mu \mathrm{gg}^{-1}\right)$ \\
\hline \multirow{4}{*}{$\mathrm{NY}_{2}$} & 0 & $8.7^{\mathrm{a}}$ & $5.2^{\mathrm{a}}$ & $5.9^{\mathrm{a}}$ & $9.4^{\mathrm{a}}$ & $8.9^{\mathrm{a}}$ \\
\hline & 2.5 & $13^{\mathrm{c}}$ & $6.9^{c}$ & $20^{c}$ & $70^{\mathrm{a}}$ & $47^{\mathrm{b}}$ \\
\hline & 5 & $8.3^{\mathrm{b}}$ & $12^{\mathrm{b}}$ & $17^{\mathrm{b}}$ & $44^{\mathrm{a}}$ & $42^{\mathrm{a}}$ \\
\hline & 10 & $15 b^{c}$ & $9^{c}$ & $20^{\mathrm{b}}$ & $56^{\mathrm{a}}$ & $45^{\mathrm{a}}$ \\
\hline \multirow{4}{*}{$\mathrm{NY}_{5}$} & 0 & $1.4^{\mathrm{c}}$ & $5.3^{\mathrm{b}}$ & $7.3^{\mathrm{a}}$ & $6.5^{\mathrm{ab}}$ & $7.5^{\mathrm{a}}$ \\
\hline & 2.5 & $7.4^{\mathrm{b}}$ & $6.6^{\mathrm{b}}$ & $14^{\mathrm{b}}$ & $45^{\mathrm{a}}$ & $47^{\mathrm{a}}$ \\
\hline & 5 & $10^{\mathrm{b}}$ & $8.9^{\mathrm{b}}$ & $14^{\mathrm{b}}$ & $61^{\mathrm{a}}$ & $78^{\mathrm{a}}$ \\
\hline & 10 & $15^{\mathrm{b}}$ & $15^{\mathrm{b}}$ & $41^{\mathrm{b}}$ & $129^{\mathrm{a}}$ & $112^{\mathrm{a}}$ \\
\hline
\end{tabular}

Different letters within a row indicate the significant differences among the forms $(P \leq 0.05, n=3)$.

protecting leaves because $\mathrm{NaCl}$ extracts mainly Cd-pectates, Cd-polypeptide, or Cd-protein.

\section{Discussion}

4.1. Cd Distribution in Cells of Roots. Cd concentration showed the same order (root $>$ stem $>$ leaf $>$ tuber) and $\mathrm{Cd}$ accumulation in plant components showed the order of stem $>$ leaves $>$ roots for both $\mathrm{NY}_{2}$ and $\mathrm{NY}_{5}$ in previous work [12]. Cd chemical forms in plants were linked with $\mathrm{Cd}$ transporting activity, among which $\mathrm{F}_{\mathrm{R}}$ and $\mathrm{F}_{\mathrm{W}}$ were the strongest; secondly, $\mathrm{F}_{\mathrm{NaCl}}, \mathrm{F}_{\text {Acet }}$, and $\mathrm{F}_{\mathrm{HCl}}$ were the weakest [16]. Most of Cd enriched in roots after absorbing by plants and the amount transported up to shoots was usually a little [17]. Cd concentrated in roots which might be related to $\mathrm{Cd}$ that formed stable large molecule complex with protein, polysaccharide, ribose, and nuclein in roots, deposited [18], and then lightened poisoning to organs in shoots. Cd accumulation in roots is usually accredited to cell wall [19]. Cell wall is the first protective screen protecting cell protoplast from being harming by heavy metals. Cellulose, hemicelluloses, xylogen, and pectic substance which consist of cell wall have abundant active perssads, such as carboxyl, oxhydryl, and aldehyde group. A part of external Cd being passed through will combine with these perssads. It prevents large amount of $\mathrm{Cd}$ from going into plasma and reduces toxicity [16]. Especially in the condition of short time and low concentration, this tolerance system of the combination of Cd and cell wall is most important [20]. However, some scholars consider oppositely that the amount of Cd combined with root cell wall is much less than that in the cell $[19,21$, 22]. Vacuole is a Cd accumulating place in higher plants, but not the main point, only in the condition of high $\mathrm{Cd}$ concentration $[19,23]$. As can be seen from Table 3 , the absolute advantage laid with the $\mathrm{F}_{\mathrm{NaCl}}$ ratio, showing that $\mathrm{Cd}$ mainly adheres to protein. This is because that $\mathrm{Cd}$ has very strong affinity with protein or hydrosulphonyil in other organic compounds [24]. On the one hand, the combination of $\mathrm{Cd}$ and protein in plants can decrease the amount of free $\mathrm{Cd}$, reducing its availability and mobility and avoiding harm to plants. Cd also may be combined with enzymes and functional proteins, disturbing their regular function and disordering physiological and biochemical metabolism [25]. Because of the higher $\mathrm{F}_{\mathrm{w}}$ ratio and the lower $\mathrm{F}_{\text {Acet }}$ ratio, the amount of Cd is more poisonous and is transported more quickly in $\mathrm{NY}_{2}$ than that in $\mathrm{NY}_{5}$, with $\mathrm{NY}_{2}$ showing fewer biomass of roots in some degree and $\mathrm{NY}_{5}$ showing normal for the growth of 20 days.

4.2. Cd Transporting from Roots to Shoots. The transporting of $\mathrm{Cd}$ from roots to shoots and accumulated in shoots is a very complicated process. There are many studies on it [26]. It is usually considered that $\mathrm{Cd}$ absorbed by roots is transported to other components in plants through the xylem. Root metal ions go into root vascular bundle through endoderm and the inner casparian strip. Passing through casparian strip is difficult, so this translocation is mainly carried out in young roots in which casparian strip has not been formed completely [27]. Then mental ions may be transported up to shoots by transpiration. There are many reports on longdistance translocation and the system of Cd long-distance translocation in plants is controversial. The $\mathrm{F}_{\mathrm{w}}$ and $\mathrm{F}_{\mathrm{NaCl}}$ ratios were reduced substantially in both $\mathrm{NY}_{2}$ and $\mathrm{NY}_{5}$, so compared to control, stems did not suffer toxicity in $\mathrm{NY}_{5}$ while except when at the Cd concentration of $10 \mathrm{mg} \mathrm{L}^{-1}$ and the biomass of stem in $\mathrm{NY}_{2}$ decreased by small degrees.

4.3. Cd Accumulation and Distribution in Leaves. Cd in leaf cells mainly comes from the water translocation from vascular bundle to leaf tissue which indicates that transpiration plays an important role in heavy mental accumulation [19]. Similar to root cells, the combination of leaf cell wall and Cd decreases Cd concentration in cell sap, lightening toxicity to leaf cells. However, the interception of cell wall plays a secondary role and the main detoxication mechanism is in the vacuole [19]. There are rich small molecule substances, such as GSH, oxalic acid, histidine, citrate, and phosphoric acid in vacuole. $\mathrm{Cd}$ avoids contacting with organelle to realize $\mathrm{Cd}$ detoxication through chelation or laydown with those small molecule substances [28, 29]. Compared to other chemical forms, the $\mathrm{F}_{\text {Acet }}$ ratios have absolute advantage in both two Jerusalem artichoke genotypes showing that a considerable part of $\mathrm{Cd}$ tends to form insoluble phosphate in leaves; accordingly, the amount of free $\mathrm{Cd}$ which is poisonous becomes low (Table 5). Therefore, from the appearance, there is almost no remarkable difference between the biomass of treatment group and that of control group in $\mathrm{NY}_{2}$ and $\mathrm{NY}_{5}$ leaves. Previous studies have documented that $\mathrm{Cd}$ exists and 
transports in ion form in some certain plants [30, 31]. But in some Cd-accumulators, Cd existence is mostly in organic combination [31].

\section{Conclusions}

In summary, $\mathrm{Cd}$ toxicity and tolerance mechanism are most complex. Different plants, even different strains of the same plant or different ecological types, may show diverse Cd tolerance ability and mechanism. According to the previous study, compared with $\mathrm{NY}_{2}$, genotype $\mathrm{NY}_{5}$ may be a better candidate for phytoremediation of and biofuel production on Cd-contaminated soils. The present study implied that in high accumulator, namely, $\mathrm{NY}_{5}$, the complex of insoluble phosphate tends to be shaped more easily which is much better for $\mathrm{Cd}$ accumulation. Besides, translocation from plasma to vacuole after combination with protein may be one of the main mechanisms in Cd-accumulator Jerusalem artichoke genotypes.

\section{Conflict of Interests}

The authors declare that there is no conflict of interests regarding the publication of this paper.

\section{Authors' Contribution}

Xiaohua Long and $\mathrm{Ni} \mathrm{Ni}$ contributed to the paper equally.

\section{Acknowledgments}

The authors are grateful for the financial support of National Natural Science Foundation of China (no. 31201692), the National Key Projects of Scientific and Technical Support Programs funded by the Ministry of Science and Technology of China (no. 2011BAD13B09), the Project of a Special Fund for Public Welfare Industrial (Agriculture) Research of China (no. 200903001-5), the Ministry of Science and Technology of Jiangsu Province (no. BE2011368), and Fundamental Research Funds for Central Universities (no. Y0201100249).

\section{References}

[1] M. Halim, P. Conte, and A. Piccolo, "Potential availability of heavy metals to phytoextraction from contaminated soils induced by exogenous humic substances," Chemosphere, vol. 52, no. 1, pp. 265-275, 2003.

[2] M. B. Kirkham, "Cadmium in plants on polluted soils: effects of soil factors, hyperaccumulation, and amendments," Geoderma, vol. 137, no. 1-2, pp. 19-32, 2006.

[3] T. Arao and N. Ae, "Genotypic variations in cadmium levels of rice grain," Soil Science and Plant Nutrition, vol. 49, no. 4, pp. 473-479, 2003.

[4] G. Ondrasek, D. Romic, Z. Rengel, M. Romic, and M. Zovko, "Cadmium accumulation by muskmelon under salt stress in contaminated organic soil," Science of the Total Environment, vol. 407, no. 7, pp. 2175-2182, 2009.

[5] G. Ondrasek, Z. Rengel, D. Romic, and R. Savic, "Salinity decreases dissolved organic carbon in the rhizosphere and increases trace element phyto-accumulation," European Journal of Soil Science, vol. 63, pp. 685-693, 2012.

[6] G. J. Wagner, "Accumulation of cadmium in crop plants and its consequences to human health," Advances in Agronomy, vol. 51, pp. 173-212, 1993.

[7] I. D. Pulford and C. Watson, "Phytoremediation of heavy metal-contaminated land by trees-a review," Environment International, vol. 29, no. 4, pp. 529-540, 2003.

[8] N. T. H. Ha, M. Sakakibara, S. Sano, R. S. Hori, and K. Sera, "The potential of eleocharis acicularis for phytoremediation: case study at an abandoned mine site," Clean-Soil, Air, Water, vol. 37, no. 3, pp. 203-208, 2009.

[9] D. Lin, Y. Ouyang, C. H. Huang, and D. Y. Huang, "Characterization of heavy metals from banana farming soils," Clean-Soil, Air, Water, vol. 38, no. 5-6, pp. 430-436, 2010.

[10] L. Chen, X. Long, Z. Zhang, X. Zheng, Z. Rengel, and Z. Liu, "Cadmium accumulation and translocation in two Jerusalem artichoke (Helianthus tuberosus L.) cultivars," Pedosphere, vol. 21, no. 5, pp. 573-580, 2011.

[11] T. Ni and Y. Wei, "Subcellular distribution of cadmium in mining ecotype Sedum alfredii," Acta Botanica Sinica, vol. 45, no. 8, pp. 925-928, 2003.

[12] X. H. Long, N. Ni, L. Wang et al., "Phytoremediation of cadmium-contaminated soil by two Jerusalem artichoke (Helianthus tuberosus L.) genotypes," Clean-Soil Air Water, vol. 41, no. 2, pp. 202-209, 2013.

[13] J. L. Xu, Z. P. Bao, J. R. Yang, H. Lu, and W. C. Song, "Chemical forms of $\mathrm{Pb}, \mathrm{Cd}$ and $\mathrm{Cu}$ in crops," Chinese Journal of Applied Ecology, vol. 2, no. 3, pp. 244-248, 1991.

[14] F. Wu, J. Dong, Q. Q. Qiong, and G. Zhang, "Subcellular distribution and chemical form of $\mathrm{Cd}$ and $\mathrm{Cd}-\mathrm{Zn}$ interaction in different barley genotypes," Chemosphere, vol. 60, no. 10, pp. 1437-1446, 2005.

[15] Z. M. Yang, S. J. Zheng, and A. T. Hu, "Accumulaion, chemical forms and physiological characteristic of cadmium in plants affected by phosphorus," Chinese Journal of Applied and Environmental Biology, vol. 6, no. 2, pp. 121-126, 2000.

[16] Y. Sun, Q. Zhou, W. Liu, J. An, Z. Xu, and L. Wang, "Joint effects of arsenic and cadmium on plant growth and metal bioaccumulation: a potential Cd-hyperaccumulator and Asexcluder Bidens pilosa L," Journal of Hazardous Materials, vol. 165, no. 1-3, pp. 1023-1028, 2009.

[17] J. M. Kelly, G. R. Parker, and W. W. McFee, "Heavy metal accumulation and growth of seedlings of five forest species as influenced by soil cadmium level," Journal of Environmental Quality, vol. 8, no. 3, pp. 361-364, 1979.

[18] Y. Uysal and F. Taner, "Bioremoval of cadmium by Lemna minor in different aquatic conditions," Clean-Soil, Air, Water, vol. 38, no. 4, pp. 370-377, 2010.

[19] M. Wójcik, J. Vangronsveld, J. D’Haen, and A. Tukiendorf, "Cadmium tolerance in Thlaspi caerulescens II. Localization of cadmium in Thlaspi caerulescens," Environmental and Experimental Botany, vol. 53, no. 2, pp. 163-171, 2005.

[20] G. Wu, H. Kang, X. Zhang, H. Shao, L. Chu, and C. Ruan, "A critical review on the bio-removal of hazardous heavy metals from contaminated soils: issues, progress, eco-environmental concerns and opportunities," Journal of Hazardous Materials, vol. 174, no. 1-3, pp. 1-8, 2010.

[21] W. E. Rauser and C. A. Ackerley, "Localization of cadmium in granules within differentiating and mature root cells," Canadian Journal of Botany, pp. 643-646, 1987. 
[22] M. D. Vzquez, C. Poschenrieder, and J. Barce, "Ultrastructural effects and localization of low cadmium concentrations in bean roots," New Phytologist, vol. 120, no. 2, pp. 215-226, 1992.

[23] V. S. Bezel, T. V. Zhuikova, and V. N. Pozolotina, "The structure of dandelion cenopopulations and specific features of heavy metal accumulation," Russian Journal of Ecology, vol. 29, no. 5, pp. 331-337, 1998.

[24] J. R. Yang, J. Q. He, and G. X. Zhang, "Tolerance mechanism of crops to Cd pollution," Journal of Applied Ecology, vol. 6, no. 1, pp. 87-91, 1995.

[25] G. Q. Chen and X. J. Zhang, "Cd accumulation, chemical form and physiology characteristic in pepper by Zinc," Environmental Science, vol. 31, no. 7, pp. 1657-1662, 2010.

[26] U. Kramer, "Cadmium for all meals-plants with an unusual appetite," New Phytologist, vol. 145, no. 1, pp. 1-5, 2000.

[27] R. T. Hardiman and B. Jacoby, "Absorption and translocation of Cd in bush beans (Phaseolus vulgaris)," Physiologia Plantarum, vol. 61, no. 4, pp. 670-674, 1984.

[28] H. Nishizono, H. Ichikawa, S. Suziki, and F. Ishii, "The role of the root cell wall in the heavy metal tolerance of Athyrium yokoscense," Plant and Soil, vol. 101, no. 1, pp. 15-20, 1987.

[29] H. J. Weigel and H. J. Jager, "Subcellular distribution and chemical form of cadmium in bean plants," Plant Physiology, vol. 65 , no. 3, pp. 480-482, 1980.

[30] C. B. Jagna, L. Isabelle, L. Stanley, and D. Joanna, "Short term signaling responses in roots of young soybean seedlings exposed to cadmium stress," Journal of Plant Physiology, vol. 170, pp. 1585-1594, 2013.

[31] A. P. G. C. Marques, H. Moreira, A. R. Franco, A. O. S. S. Rangel, and P. M. L. Castro, "Inoculating Helianthus annuus (sunflower) grown in zinc and cadmium contaminated soils with plant growth promoting bacteria-effects on phytoremediation strategies," Chemosphere, vol. 92, pp. 74-83, 2013. 

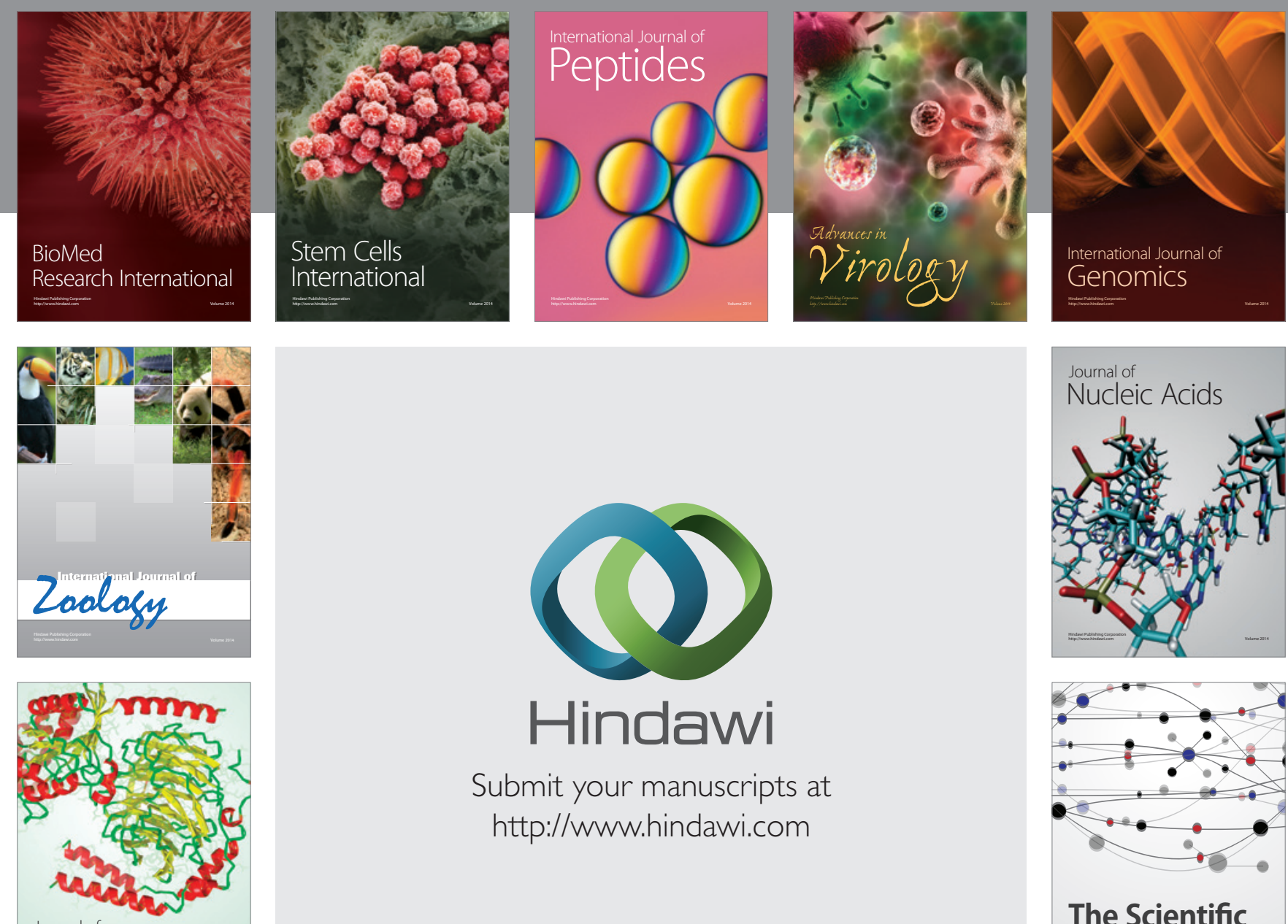

Submit your manuscripts at

http://www.hindawi.com

Journal of
Signal Transduction
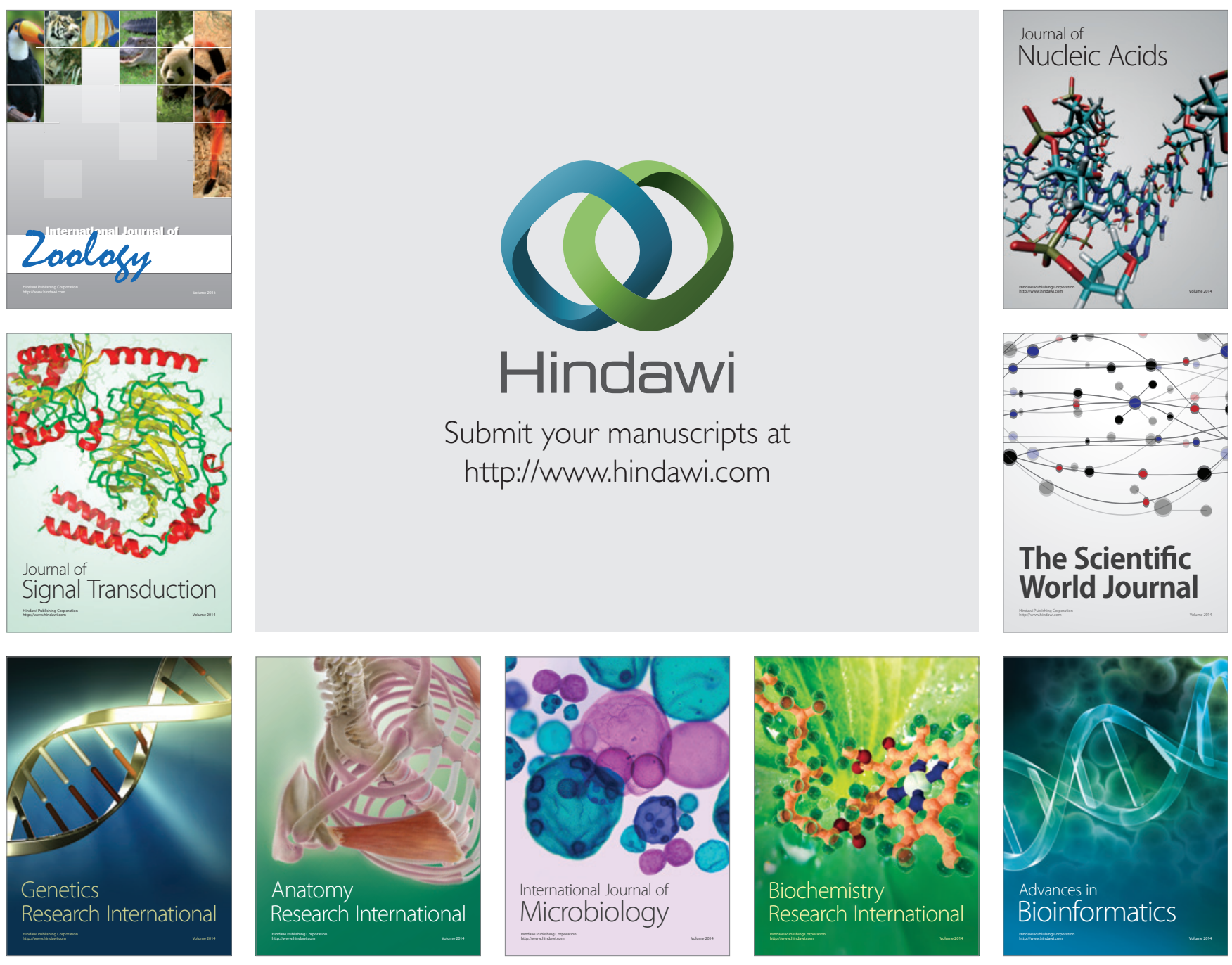

The Scientific World Journal
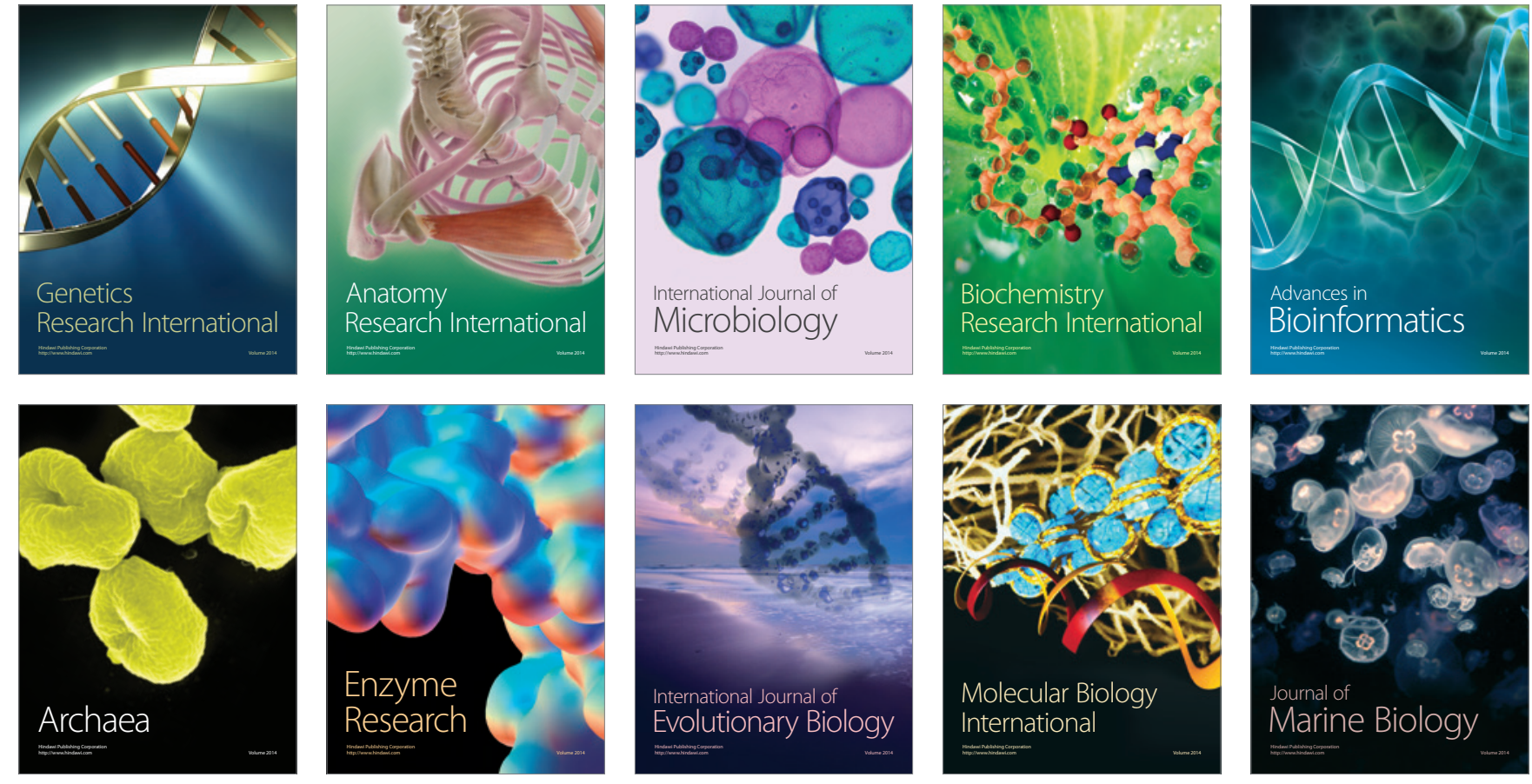